\title{
PI-Based Separation of Tissue Proteins Realized with the Use of Two- Dimensional Gel Electrophoresis or Alternatively Capillary Isoelectric Focusing
}

\author{
Ilona Olędzka ${ }^{1}$, Kamil Włodarski ${ }^{1}$, Piotr Kowalski ${ }^{1}$, Jolanta Grzenkowicz-Wydra ${ }^{2}$, Jolanta \\ Paradziej-Łukowicz ${ }^{3}$, Tomasz Bączek ${ }^{1, *}$ \\ ${ }^{I}$ Department of Pharmaceutical Chemistry, Medical University of Gdańsk, Hallera 107, 80-416 Gdańsk, Poland \\ ${ }^{2}$ Pomeranian Science and Technology Park, Gdynia, Poland \\ ${ }^{3}$ Tri-City Central Animal Laboratory - Research and Service Centre, Medical University of Gdańsk, Gdańsk, Poland
}

\begin{abstract}
A two-dimensional gel electrophoresis (2D-GE) and capillary isoelectric focusing (cIEF) were performed subsequently to analyze protein mixtures from laboratory animal tissues (liver, muscle, and mammary gland). Both techniques were compared and evaluated. It was found that cIEF can be a valuable alternative in comparison to 2D-GE. Especially considering the goals associated with the determination of far the separated proteins, cIEF possesses perspective analytical advantages.
\end{abstract}

Keywords: Two-dimensional gel electrophoresis (2D-GE), Capillary isoelectric focusing (cIEF), Animal tissue.

\section{INTRODUCTION}

Clinical proteomics employs two main technological approaches. On the one hand, a combination of proteins and peptides separation technique and mass spectrometry to discover biological biomarkers of disease and, on the other hand, protein microarrays to use the biomarkers discovered for diagnostic or therapeutic purposes.

The most widely used method for protein separation in proteomics is two-dimensional polyacrylamide gel electrophoresis (2-D PAGE), otherwise known as two-dimensional gel electrophoresis (2D-GE), an analytical technique with a high power of resolution. The proteins are first separated by isoelectric focusing (IEF), which stratifies them on the basis of their isoelectric points, and the second dimension is sodium dodecyl sulphate (SDS)-polyacrylamide gel electrophoresis, which separates the proteins on the basis of their molecular weight. 2D-GE is a very efficient method and allows the specification of several thousand proteins in a single study. It was presented for the first in 1975 by Patrick O'Farrell from the University of California at San Francisco [1]. Two-dimensional electrophoresis in polyacrylamide gel in the seventies of last century was used for separation of proteins and comparative analysis of tissues of healthy and sick individuals [2]. This method created the possibility of separation, detection and isolation even more than 1000 different proteins in one sample. Time-consuming, laborintensive, many critical steps, and lack of uniform

*Address correspondence to this author at the Department of Pharmaceutical Chemistry, Medical University of Gdańsk, Hallera 107, 80-416 Gdańsk, Poland; Tel: +48 58 3491635; Fax: +48 58 3491635;

E-mail: tbaczek@gumed.edu.pl procedures for all biological materials, decided that the popularity of $2 \mathrm{D}-\mathrm{GE}$ is a disproportionately small for the opportunities that pose. However, recently its importance has been increased and is considered still as one of the basic methods for creating maps of the human proteome. Very interesting is the work done by Zenzmaier in 2005, on proteomic profiling of human stem cells derived from umbilical cord blood using 2D-GE [3]. One of the latest work on the use of 2D electrophoresis is analysis of the salivary proteome in gingivitis patients [4].

Last two decades is characterized by dynamic development of modern, fully automated instrumental methods of separation, effective both in terms of time and cost of implementation. Almost every year there are newer and improved facilities that meet a number of different analytical purposes. The development of detection techniques have to meet the growing demands in biomedical analysis. At the same time, it becomes necessary to develop new, more efficient, and sensitive methods of separation of proteins in biological material. Among many methods that are used in biomedical analysis, an electrophoretic techniques are increasingly becoming the method of choice. Most of the proteomic studies cannot be done without preliminary separation of a mixture of proteins by one- or two-dimensional electrophoresis. Identification of a large number of proteins can detect those whose expression is altered in pathological cells.

The capillary format of isoelectric focusing (cIEF) was born around 1985 when Hjerten and Zhu decided to adapt the equipment for high-performance electrophoresis to isoelectric focusing [5]. Isoelectric focusing in the capillary (cIEF) is one of the latest methods of electrophoresis and is 
based on the distribution of compounds based on their isoelectric point. The advantage of this method over traditional gel-focusing lays due to its speed, automation and detection of small volume of samples collected for testing. However, the idea of separation and main reagents used in cIEF, such as ampholyte, remain unchanged. The cIEF is a method that uses the fact that particles move only if they have an electric charge. The cIEF separation consists of two steps: focusing and mobilization [6]. The examples of separation of new $\mathrm{pI}$ markers together with derivatized proteins by capillary IEF with photometric or fluorometric detection by Horka was presented [7]. Most publications using cIEF concerns proteomics and biopharmaceutical applications [813].

The aim of this study was to compare the protein profile received from rat tissues (liver, muscle and mammary gland) obtained by 2D-GE in denaturing conditions (SDS-2D-GE) and capillary isoelectric focusing (cIEF). In addition to the selection of appropriate conditions for separation, the electrophoretic methods used in technical terms were compared and the assessment of protein profiles of three rat tissues was done.

\section{MATERIALS AND METHODS}

\section{Reagents}

The protein pI markers: (IEF Standards) for 2D experiments were obtained from BioRad (BioRad, Hercules, CA, USA), in turn cIEF Peptide Markers pI 10.0, 9.5, 7.0, 5.5 and 4.1 for cIEF experiments were obtained from Beckman Coulter (Beckman Coulter, Fullerton, CA, USA). Biochemical grade urea, SDS, ampholytes $\mathrm{pH} 3-10$, Tris, TEMED, glycine, acrylamide solution, glycerol, iodoacetamide, DTT, CHAPS and Bio-Rad DC Protein Assay were purchased from BioRad (BioRad, Hercules, CA, USA). Phosphoric acid, sodium hydroxide, acetic acid, arginine, iminodiacetic acid, natrium tiosulphate were obtained from Sigma-Aldrich (St. Louis, MA, USA). Sodium carbonate, formaldehyde and methanol were purchased from Merck (Darmstadt, Germany). All reagents were of the analytical reagent grade. Highly pure water was obtained from Milli-Q water system (Millipore, Bradford, MA, USA).

\section{Apparatus}

2D experiments were carried out on Protean IEF Cell (Bio-Rad) and PROTEAN II xi 2-D Cell (Bio-Rad, Hercules, CA, USA ). The P/ACE MDQ capillary electrophoresis system (Beckman Instruments, Fullerton, CA, USA), equipped with an UV detection system for capillary isoelectric focusing experiments was also used. The Polytron homogenization apparatus PT 2100 from Kinematica (LittauLucerne, Switzerland) for homogenization of rat tissue samples was used.

\section{Two-dimensional Gel Electrophoresis}

\section{Sample Preparation Procedure}

Appropriate sample preparation is equally important as proper gel polymerization and the preparation of electrolytes. Each type of electrophoresis technique requires different conditions for sample preparation [14]. In all cases, the separated sample may not contain too much salt, which in the ionized form distorts migration and broadening the peaks in the electropherograms.

Once thawed, homogenized tissues were centrifuged for $6 \mathrm{~min}$ at $10000 \mathrm{rpm}$ and the supernatant was placed in clean Eppendorf tubes. Then the protein concentration was determined in individual samples in order to download its volume corresponding to the further procedure. Literature data indicate that the weight of protein taken for further analysis, when used strip IPG $11 \mathrm{~cm}$ in length and protein staining with silver, should be within the limits of 20-50 $\mu \mathrm{g}$. To determine the concentration of protein used a set of DC Protein Assay reagents (BioRad, Hercules, CA, USA), standard solutions of bovine serum albumin and apparatus for measuring the absorbance Multiscan FC (Thermo Scientific, Waltham, MA, USA). Dependence of absorbance on concentration for standard solutions, after averaging two absorbance values for each of the concentrations, led to the linear function $\mathrm{y}=\mathrm{ax}+\mathrm{b}$, where $\mathrm{y}$ is the absorbance, and $\mathrm{x}$ is the concentration expressed in $\mathrm{mg} / \mathrm{ml}$. The equation $(\mathrm{y}=0.1115 \mathrm{x}+$ 0.0163 ) allowed the calculation of protein concentration in individual tissue samples. The measured values of protein concentration in liver, muscle and mammary gland samples were $10.025 \mathrm{mg} / \mathrm{ml}, 4.83 \mathrm{mg} / \mathrm{ml}$ and $3.08 \mathrm{mg} / \mathrm{ml}$, respectively.

Analyses of rat tissues protein profiles were performed on ready IEF strips pH 3-10 $11 \mathrm{~cm}$ IPG (BioRad, Hercules, CA, USA), in buffer containing neutral denaturing chaeotrop and a mixture of amphoteric ions. After isoelectrofocusing process, stripes were equilibrated in the buffer, and then the protein were separated on a gradient polyacrylamide gel.

\section{Rehydration and Isoelectric Focusing Steps}

In the next stage, the $10 \mathrm{ml}$ of rehydration buffer of the following composition: $8 \mathrm{M}$ urea, 2\% CHAPS, $0.77 \%$ DTT, $0.2 \%$ ampholyte and $0.002 \%$ Bromophenol Blue according to the manufacturer's instructions was prepared. To Eppendorf tube, the required volume of tissue homogenate was added and filled with rehydration buffer to $200 \mu 1$. The tube was shaken for half a minute to mix the ingredients. In this way, prepared sample to the strip was applied and left overnight in room temperature. The next day, strip was placed in the apparatus Protean IEF Cell (BioRad, Hercules, CA, USA) and the separation was performed at room temperature for $15 \mathrm{~min}$ at $250 \mathrm{~V}, 180 \mathrm{~min}$ at $450 \mathrm{~V}, 6000 \mathrm{~min}$ at $8000 \mathrm{~V}$ and $15 \mathrm{~min}$ at $500 \mathrm{~V}$.

\section{Equilibration Step}

Prior to the second dimension analysis, the strips were equilibrated for $10 \mathrm{~min}$ in $3 \mathrm{ml}$ equilibration solution (6M Urea, $0.375 \mathrm{M}$ Tris $\mathrm{HCl} \mathrm{pH} 8.8,2 \%$ SDS, 20\% glycerol and $2 \%$ DTT) and subsequently for another $10 \mathrm{~min}$ in $3 \mathrm{ml}$ of alkylation solution (6M Urea, $0.375 \mathrm{M}$ Tris $\mathrm{HCl} \mathrm{pH} \mathrm{8.8,} \mathrm{2 \%}$ SDS, $20 \%$ glycerol and $2.5 \%$ iodoacetamide).

\section{Second Dimension (Sodium Dodecylsulfate-polyacrylamide Gel Electrophoresis, SDS-PAGE)}

The second-dimension (SDS-PAGE) was performed in gel formulation comprising $12 \% \mathrm{~T}$ and $2.67 \% \mathrm{C}$, prepared by 
mixing $33.5 \mathrm{ml}$ deionized water, $25 \mathrm{ml}$ of $1.5 \mathrm{M}$ TRIS/ $\mathrm{HCl}$ at $\mathrm{pH} 8.8,1 \mathrm{ml}$ of $10 \% \mathrm{SDS}, 40 \mathrm{ml}$ of $30 \%$ acrylamide solution, $1 \mathrm{ml}$ of $10 \%$ APS and $50 \mu \mathrm{l}$ of TEMED. Protein molecular weight marker was applied to the well provided on the gel for calibration of the molecular weight. Like Werner [15], in the second-dimension one employed the standard Laemmli buffer system. The basic electrophoresis buffer ( 25 mM TRIS, $192 \mathrm{mM}$ glycine and 0.1\% SDS) was made up a $10 \mathrm{x}$ stock which was diluted to the appropriate concentration. The runs were performed in PROTEAN II xi 2-D Cell (BioRad, Hercules, CA, USA) at $200 \mathrm{~V}$ for $5 \mathrm{~h}$.

\section{Silver Stain Procedure}

Silver Stain is about 10 to 100 times more sensitive than Coomasie Blue Staining. Estimation of protein amounts is not advisable since the staining intensity depends on the developing time and vary from protein to protein. All volumes of staining solution in the experiments prepared were $300 \mathrm{ml}$ for $1.5 \times 160 \times 160 \mathrm{~mm}$ gel (large gel). The gel was shaken gently and continuously in the solution throughout all incubation. After completion of electrophoresis, gels were placed in a fixative solution composed of $50 \%$ methanol and $5 \%$ acetic acid and left overnight. Then the gels were washed with 50\% methanol and three times with deionized water (DDW). Sensitization was carried out for $3 \mathrm{~min}$ in $200 \mathrm{ml}$ of $0.02 \% \mathrm{Na} 2 \mathrm{~S} 2 \mathrm{O} 3$ solution. Again, one washed twice with deionized water. Then the gels were stained for $45 \mathrm{~min}$ in $0.15 \%$ silver nitrate solution and rinsed rapidly three times with DDW. Next, they were treated rapidly three times with a small volume of developer $(0.04 \%$ formaldehyde in $100 \mathrm{ml}$ $2 \%$ sodium carbonate) with intensive shaking, until the brown protein bands reach desired intensity. It was very important to prepare the developer just before use. The reaction was stopped by using 5\% acetic acid for $2 \mathrm{~min}$. If the $\mathrm{pH}$ remained too high, development was not stopped, and if the $\mathrm{pH}$ was too low, the gel bleached. Next, gels were stored in solution composed with $1 \%$ acetic acid and $50 \%$ methanol.

\section{Capillary Isoelectric Focusing (CIEF)}

\section{cIEF Solution and Sample Preparation Procedure}

In order to conduct experiments using capillary isoelectric focusing the following reagents were prepared: anolyte (200 $\mathrm{mM}$ phosphoric acid), catholyte $(300 \mathrm{mM}$ sodium hydroxide), chemical mobilizer (350 $\mathrm{mM}$ acetic acid), cathodic stabilizer (500 mM arginine), anodic stabilizer (200 mM iminodiacetic acid), urea solution (4.3 M) and 3M urea with ready cIEF gel.

The cIEF sample was a mixture of ampholytes, stabilizers, pI markers and the proteins of interest. The protein solution should not contain more than $50 \mathrm{mM}$ of salt. For cIEF, $10 \mu \mathrm{l}$ of sample containing proteins in the concentration range 5$10 \mathrm{mg} / \mathrm{ml}$ was prepared by mixing with $200 \mu \mathrm{l}$ of $3 \mathrm{M}$ urea, $12 \mu \mathrm{l}$ of $3-10 \mathrm{pH}$ ampholytes, $20 \mu \mathrm{l}$ cathodic stabilizer (500 $\mathrm{mM}$ arginine), $2 \mu \mathrm{l}$ of anode stabilizer (200 mM iminodiacetic acid), and $2 \mu \mathrm{l}$ each of $\mathrm{pI}$ markers (pI 4.1, 5.5, 7.0, $9.5,10.0)$. After centrifugation the sample was injected into the capillary.

\section{Separation Procedure}

The P/ACE MDQ - capillary electrophoresis instrument utilizing UV absorbance detection at $280 \mathrm{~nm}$ (Beckman
Coulter, Fullerton, CA, USA) was used for all protein cIEF separation. The system was fitted with $50 \mu \mathrm{m}$ i.d. neutral capillary (Beckman Coulter, Fullerton, CA, USA) with 30.2 $\mathrm{cm}$ total length $(20.0 \mathrm{~cm}$ effective length). Sample storage and cartridge temperature were maintained at $20^{\circ} \mathrm{C}$. It was very important not to expose the neutral-coated capillary ends to air for more than five minutes. Over five minutes of exposure one can cause irreversible damage to the capillary coating. When the capillary was not in use, the capillary ends in vials filled with deionized water were placed. Before each separation, capillary was rinsed for $5 \mathrm{~min}$ at 50 psi with deionized water, for $2 \mathrm{~min}$ at 50 psi with chemical mobilizer, for $5 \mathrm{~min}$ at $50 \mathrm{psi}$ with $\mathrm{cIEF}$ gel. Isoelectric focusing process in a capillary consisted of the following stages: rinsing the capillary for $3 \mathrm{~min}$ at $50 \mathrm{psi}$ with urea solution, rinsing for 2 min at 50 psi with deionized water, injecting sample for $99.9 \mathrm{~s}$ at $25 \mathrm{psi}$, focusing for $15 \mathrm{~min}$ at $25 \mathrm{kV}$ under normal polarity, chemical mobilizing for $30 \mathrm{~min}$ at $30 \mathrm{kV}$ under normal polarity. After analysis, ends the capillary should be rinsed for $2 \mathrm{~min}$ at $50 \mathrm{psi}$ with deionized water.

\section{RESULTS AND DISCUSSION}

To simultaneously analyze a large number of proteins in a certain type of tissue, 2D-GE with IEF for the first dimension and SDS-PAGE for the second dimension has been widely used $[2,4,15]$. Various conditions of protein extraction affect the number and kind of protein spots after twodimensional gel electrophoresis, therefore, a good sample preparation is essential for obtaining reproducible 2D-GE gel results.

The use of two parameters of separation (isoelectric point and molecular weight proteins) suggests that every single spot on the gel is a one protein. This allows the determination of its mass, pI, and then cut from the gel and determine the chemical structure using mass spectroscopy. This gives the advantage to $1 \mathrm{D}-\mathrm{GE}$, in which a single band may be a single protein, but also a mixture of proteins of the same weight.

Two-dimensional method additionally allows to specify the isoelectric point $(\mathrm{pI})$ of each of the separated proteins. The size and intensity of the color patches is dependent on protein concentration, which allows visual assessment of its relative amounts.

A distinctive number of stained bands in the case of the liver tissue confirmed that it is a tissue that has the high numbers of proteins (Figs. 1A and 1B). The molecular weights of the proteins were found in a wide range from 10 to $250 \mathrm{kD}$, but present in low concentrations, some even at the limit of detection. This diversity is associated with liver function, which is the organ in which there is synthesis and modification of large number of proteins. Experiments performed by cIEF confirmed that liver tissue was rich in a variety of proteins with a wide range of isoelectric point (Fig. 1B). Electropherogram of liver contained the most numerous peaks appearing between 15 and $45 \mathrm{~min}$, which can be attributed to the $\mathrm{pI}$ in the range from 5.0 to 10.0 (similarly as in the case of 2D-GE). However, as shown in the Figs. (1A and 1B), these proteins are present in low concentrations, hence the low intensity of the spots on the gel and the low height of the peaks in electropherogram. In 


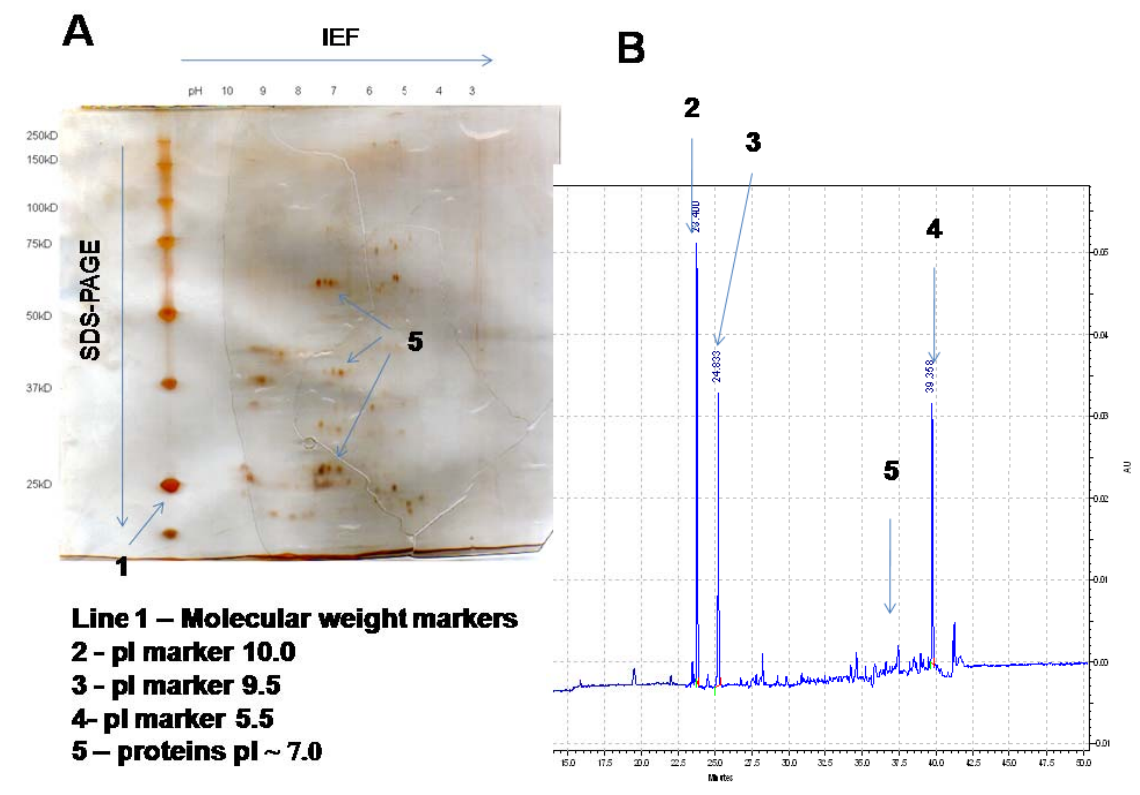

Fig. (1). Comparison of typical 2D gel silver-stained for protein visualization (A) and cIEF electropherograms (B) obtained from rat liver

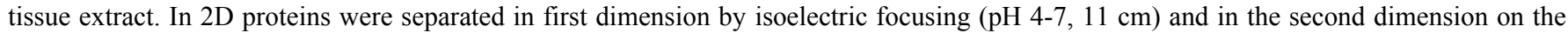
orthogonal $15 \%$ sodium dodecyl sulphate polyacrylamide gel under reducing conditions. In the case cIEF analysis - detector UV at $280 \mathrm{~nm}$, capillary $50 \mu \mathrm{m}$ i.d. and $20 \mathrm{~cm}$ effective length, injection for $99 \mathrm{~s}$ at 25 psi, focusing for $15 \mathrm{~min}$ at $25 \mathrm{kV}$ and chemical mobilizing for 30 min at $30 \mathrm{kV}$ under normal polarity.

the case of muscle tissue (Fig. 2A), the highest spot on the gel can be seen the darkest band located between 37 to 50 $\mathrm{kD}$ and in the $\mathrm{pI}$ range about 7 , which may confirm the presence of actin. It is a protein, whose molecular weight is $42 \mathrm{kD}$ and which together with myosin, is most abundant muscle protein. The gel shows that the isoelectric point of actin is at $\mathrm{pH}$ 7. However, literature data indicate, the $\mathrm{pH}$ is a little lower than 6. This discrepancy is probably due to significant salinity samples (homogenization in $0.9 \% \mathrm{NaCl}$ solution), which causes an increase in ionic strength and decrease in protein mobility in an electric field. No presence of myosin on the gel could be due to the fact that it is a protein with an unusually large mass of approximately $470 \mathrm{kD}$. Its input into the gel and separation would be possible only with a much lower value of $\% \mathrm{C}$. The presence of actin in muscle tissue was confirmed peak about 37.0 min corresponding to $\mathrm{pI}$ between 5.5 to 7.0 (Fig. 2B). In the case of the analysis of mammary tissue, large number of spots can be seen in the range from 37 to $50 \mathrm{kD}$ and $\mathrm{pI}$ range from 7 to 10. However, these proteins are present in low concentrations, it may explain the lack of the corresponding peaks on electropherogram (Figs. 3A and 3B). In turn, intense spot on the gel can be seen in the molecular weight below $25 \mathrm{kD}$ and $\mathrm{pI}$ range between 5.0 and 6.0. (Fig. 3A), which corresponds to a relatively intense peaks in electropherogram in the range of $\mathrm{pI}$ from 4.1 to 7.0 (Fig. 3B).

In the case of experiments performed using the capillary isoelectric focusing technique (cIEF), in obtaining a fully satisfactory separation prevent salinity of the sample (the same phenomenon in 2D-electrophoresis disrupts the migration of actin to its $\mathrm{pI}$ ). When preparing a protein sample for cIEF analysis, the concentration of protein in the sample must be in the range of $5-10 \mathrm{mg} / \mathrm{ml}$ and the salt con- centration below $50 \mathrm{mM}$. If the salt concentration in the sample is greater than $50 \mathrm{mM}$, it is important that before it is introduced into the capillary, sample must be desalted [16]. The increase in ionic strength above a certain value reveals to decrease ion mobility, and this may result in a lack of separation of compounds. Desalting of the sample can be done by filtration, ultrafiltration or dialysis.

The cIEF is a method that uses the fact that particles move only if they have an electric charge. In cIEF, carrier ampholyte mixtures are used to establish a stable $\mathrm{pH}$ gradient inside a capillary suspended between an acid and base reservoir. Amphoteric analytes, typically proteins, will migrate with their local electrophoretic mobility until reaching the $\mathrm{pH}$ where their net charge is zero, defined as the isoelectric point (pI) [17].

A problem is that compounds with very high isoelectric point may stop at the end of the capillary at the cathode, even through the window of the detector. In this case, the detector cannot pick them. To prevent this phenomenon, the last few centimeters of the capillary will be filled with a solution with a $\mathrm{pH}$ well above the most basic $\mathrm{pI}$ proteins. According to literature data, there is a need to use a stabilizer cathode, which may be a solution of TEMED or arginine $[5,16]$. In our experiment, $500 \mathrm{mM}$ solution of arginine was used. In this case, the $\mathrm{pH}$ gradient ended before the detection window. Proteins, which leave their pI as a result of diffusion, automatically acquired an electrical charge. This caused them to return to the appropriate $\mathrm{pH}$ range. Such a large concentration possibility decided, that the cIEF had very good resolving power in view of all capillaries methods. Additional application of the gel more strongly inhibited the movement of the diffusion and caused a protein separated 


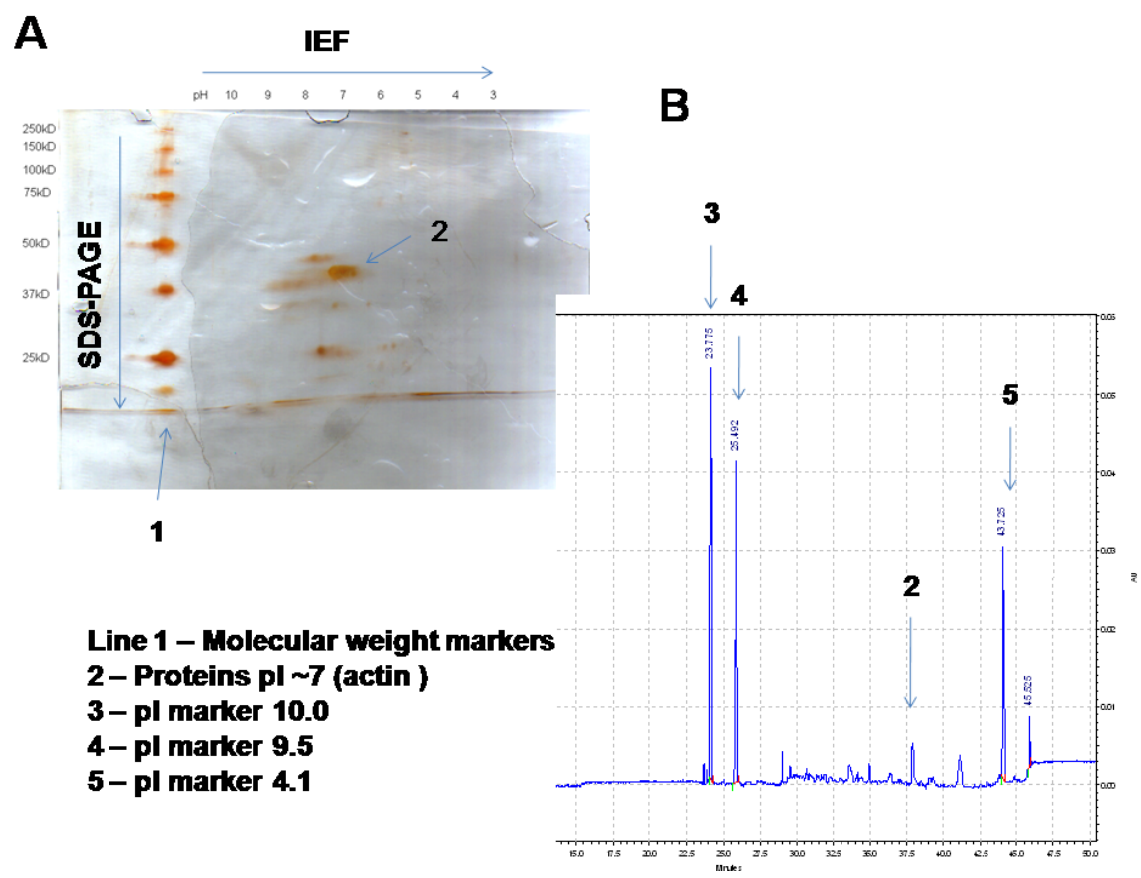

Fig. (2). Comparison of typical 2D gel silver-stained for protein visualization (A) and cIEF electropherograms (B) obtained from rat muscle tissue extract. In 2D proteins were separated in first dimension by isoelectric focusing $(\mathrm{pH} 4-7,11 \mathrm{~cm})$ and in the second dimension on the orthogonal $15 \%$ sodium dodecyl sulphate polyacrylamide gel under reducing conditions. In the case cIEF analysis - detector UV at $280 \mathrm{~nm}$, capillary $50 \mu \mathrm{m}$ i.d. and $20 \mathrm{~cm}$ effective length, injection for $99 \mathrm{~s}$ at $25 \mathrm{psi}$, focusing for $15 \mathrm{~min}$ at $25 \mathrm{kV}$ and chemical mobilizing for 30 min at $30 \mathrm{kV}$ under normal polarity.

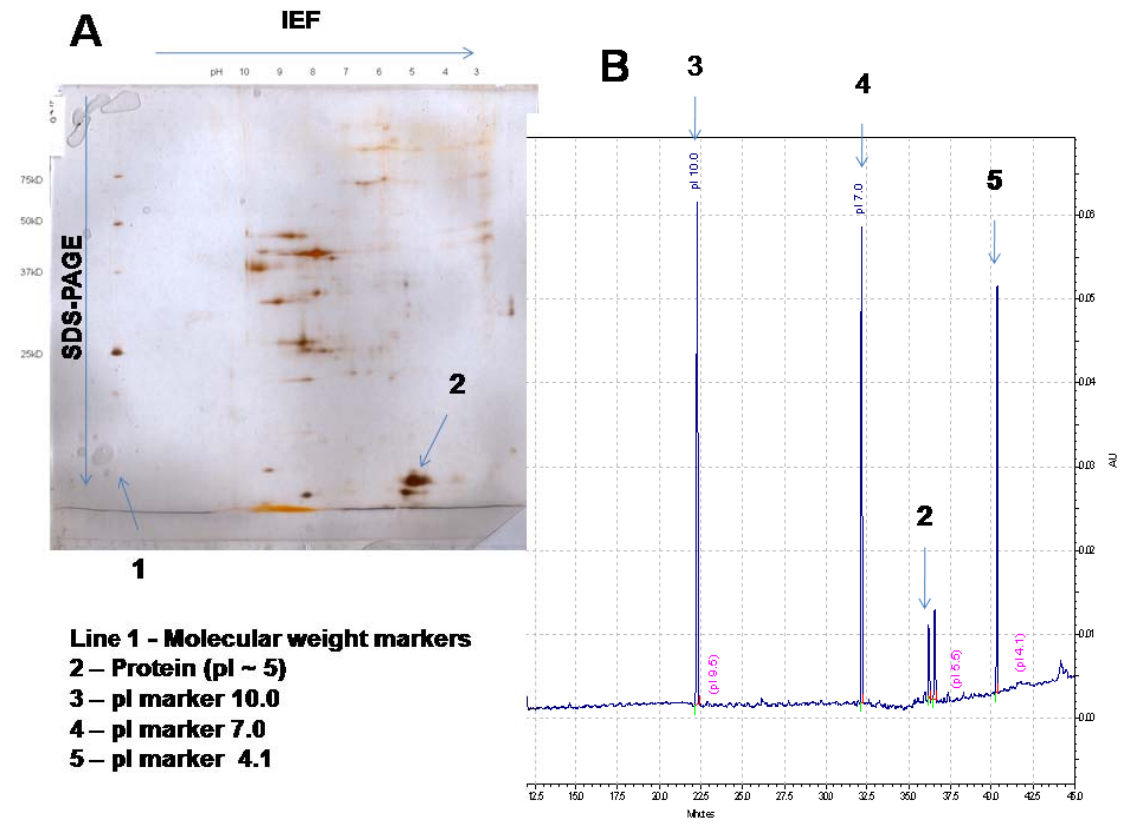

Fig. (3). Comparison of typical 2D gel silver-stained for protein visualization (A) and cIEF electropherograms (B) obtained from rat mammalian gland tissue extract. In 2D proteins were separated in first dimension by isoelectric focusing ( $\mathrm{pH} 4-7,11 \mathrm{~cm})$ and in the second dimension on the orthogonal $15 \%$ sodium dodecyl sulphate polyacrylamide gel under reducing conditions. In the case cIEF analysis - detector $\mathrm{UV}$ at $280 \mathrm{~nm}$, capillary $50 \mu \mathrm{m}$ i.d. and $20 \mathrm{~cm}$ effective length, injection for $99 \mathrm{~s}$ at $25 \mathrm{psi}$, focusing for $15 \mathrm{~min}$ at $25 \mathrm{kV}$ and chemical mobilizing for $30 \mathrm{~min}$ at $30 \mathrm{kV}$ under normal polarity.

zones extremely narrow. This is especially visible in the case of separation of a standard solution of proteins (Fig. 4).

As in the case of 2D-GE, selection of ampholyte in the case of cIEF, determines the range of $\mathrm{pH}$ gradient. Use of a mixture of ampholytes significantly different isoelectric points determines a wide range of $\mathrm{pH}$, even from 3 to 10 , while obtaining a gradient on a scale such as $2 \mathrm{pH}$ units over the entire length of the capillary was made possible to use a 


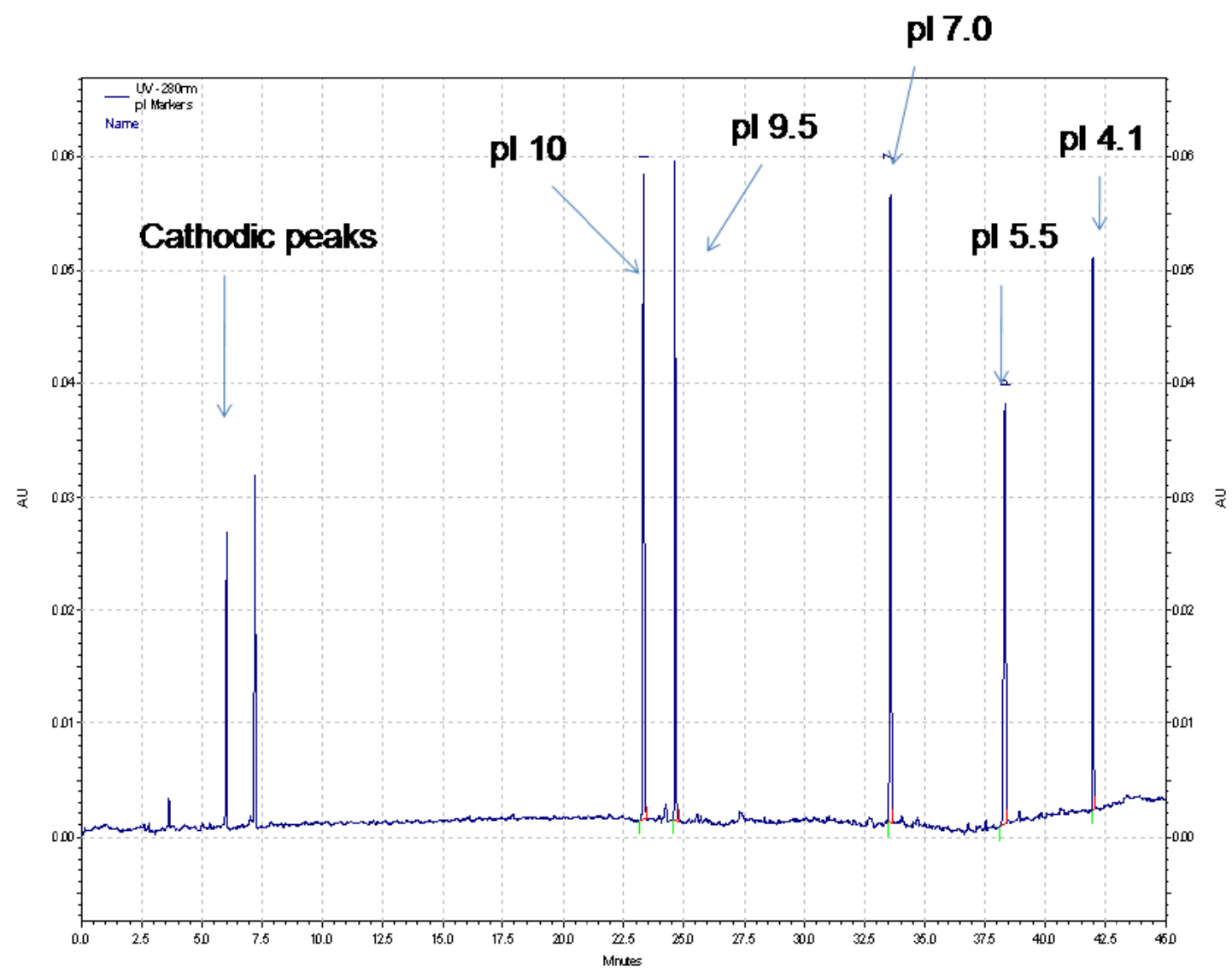

Fig. (4). Electropherogram of pI markers. Separation conditions: detector UV at $280 \mathrm{~nm}$, capillary $50 \mu \mathrm{m}$ i.d. and $20 \mathrm{~cm}$ effective length, injection for $99 \mathrm{~s}$ at $25 \mathrm{psi}$, focusing for $15 \mathrm{~min}$ at $25 \mathrm{kV}$ and chemical mobilizing for $30 \mathrm{~min}$ at $30 \mathrm{kV}$ under normal polarity.

mixture of ampholytes of similar pI values. It should be also noted that the protein in its $\mathrm{pI}$ have the lowest solubility and may be subject to precipitation, thus interfering with separation [10]. In presented work, in order to prevent precipitation of proteins, $3 \mathrm{M}$ urea to protein samples were added.

Another important step in cIEF in which, the $\mathrm{pH}$ gradient determined at the time of focusing and separation of compounds must be preserved, it is called mobilization. It is what mainly distinguishes just classical IEF from cIEF. This step can be carried out by chemical mobilization, by adding sodium chloride to the catholyte. Addition of salt to the catholyte can be replaced by the total replacement of this solution to a solution of weak acid such as acetic acid [16]. In this work, $350 \mathrm{mM}$ acetic acid as chemical mobilizer was used. Moreover, chemical mobilization requires the use of coated capillaries only because electroosmotic flow occurring in silica capillary cause broadening of the separated zones. When analyzing the electropherograms in cIEF (Figs. 1B, 2B and 3B), peaks appearing before the 15 min of the analysis can be seen. These are the cathodic peaks, which appeared at the time of injection of the sample, when proteins move in the focusing, to their isoelectric point, passing the detector window. After the start of the mobilization process the most basic protein peaks were appeared in the electropherograms as the first, followed by the compounds according to their decreasing pI (between 15 and $45 \mathrm{~min}$ of separation process).

\section{CONCLUSIONS}

In the presented work for the analysis of proteins derived from laboratory animal tissues (liver, muscle and mammary gland) two electrophoretic techniques (2D-GE and cIEF) were used. The information obtained using both techniques were compared and evaluated. Each technique allowed for detection of unique proteins that can be attributed to differences in separation mechanism. It was found that cIEF can be an alternative to 2D-GE. Especially considering the goals associated with the determination of for the separated proteins, cIEF possesses perspective analytical advantages.

\section{CONFLICT OF INTEREST}

The authors confirm that this article content has no conflicts of interest.

\section{ACKNOWLEDGEMENTS}

The work was supported by the Polish State Committee for Scientific Research Project N N405 423839. 


\section{REFERENCES}

[1] O'Farrell, P.H. High-resolution two-dimensional electrophoresis of proteins. J. Biol. Chem., 1975, 250, 4007-4021.

[2] Orrick, L.R.; Olson, M.; Busch, H. Comparison of nucleolar proteins of normal rat liver and Novikoff hepatoma ascites cells by two-dimensional polyacrylamide gel electrophoresis. Proc. Nat. Acad. Sci. USA, 1973, 70, 1316-1320.

[3] Zenzmaier, Ch.; Gesslbauer, B.; Grobuschek, N.; Jandrositz, A.; Preisegger, K.H.; Kungl, A.J. Proteomic profiling of human stem cells derived from umbilical cord blood. Biochem. Biophys. Res. Commun., 2005, 328, 968-972.

[4] Gonçalves, L da R.; Soares, M.R.; Nogueira, F.C.S.; Garcia, C.H.S.; Camisasca, D.R.; Domont, G.; Feitosa, A.C.R.; Pereira, D.A.; Zingali, R.B.; Alves, G. Analysis of the salivary proteome in gingivitis patients. J. Periodont. Res., 2011, 46, 599-606.

[5] Hjerten, S.; Zhu, M.D. Adaptation of the equipment for highperformance electrophoresis to isoelectric focusing. J. Chromatogr., 1985, 346, 265-270.

[6] Silvertand, L.H.H.; Sastre Toraño, J.; Van Bennekom, W.P.; de Jong, G.J. Recent developments in capillary isoelectric focusing. $J$. Chromatogr. A., 2008, 1204, 157-170.

[7] Horka, M.; Willimann, T.; Monika, B.; Nording, P.; Friedl, Z.; Ślais, K. Capillary isoelectric focusing with UV-induced fluorescence detection. J. Chromatogr. A., 2001, 916, 65-71.
[8] Liu, X.; Sosic, Z.; Krull, I.S. Capillary isoelectric focusing as a tool in the examination of antibodies, peptides and proteins of pharmaceutical interest. J. Chromatogr. A., 1996, 735, 165-190.

[9] Pritchett T.J. Capillary isoelectric focusing of proteins. Electrophoresis, 1996, 17, 1195-1201.

[10] Righetti, P.G.; Gelfi, C.; Conti, M. Current trends in capillary isoelectric focusing of proteins. J. Chromatogr. B., 1997, 699, 91104.

[11] Shimura, K. Recent advances in capillary isoelectric focusing: 1997-2001. Electrophoresis, 2002, 23, 3847-3857.

[12] Righetti, P.G. The Alpher, Bethe, Gamow of isoelectric focusing, the alpha-Centaury of electrokinetic methodologies. Part I. Electrophoresis, 2006, 27, 923-938.

[13] Horka, M.; Kubicek, O.; Kubesovi, A. Testing of the influenza virus purification by CIEF; Electrophoresis, 2009, 31, 331-338.

[14] Lilley, K.S.; Razzaq, A.; Dupree, P. Two-dimensional gel electrophoresis: recent advances in sample preparation, detection and quantitation. Curr. Opin. Chem. Biol., 2001, 6, 46-50.

[15] Werner, W.E. Run parameters affecting protein patterns from second dimension electrophoresis gels. Anal. Biochem., 2003, 317 280-283.

[16] Schwartz, H.E.; Palmieri, R.H.; Nolan, J.A.; Brown R. Introduction to capillary electrophoresis of proteins and peptides. Beckman Coulter: USA 1993.

[17] Weiss, N.G.; Zwick, N.L.; Hayes, M.A. Capillary isoelectric focusing coupled offline to matrix assisted laser desorption/ionization mass spectrometry. J. Chromatogr. A., 2010, 1217, 179-182.

Received: May 29, 2012

Revised: July 15, 2012

Accepted: July 28, 2012

(C) Olędzka et al.; Licensee Bentham Open.

This is an open access article licensed under the terms of the Creative Commons Attribution Non-Commercial License (http://creativecommons.org/licenses/ by-nc/3.0/) which permits unrestricted, non-commercial use, distribution and reproduction in any medium, provided the work is properly cited. 